\title{
Disquiet in the House of Gender
}

\section{GAIL HERSHATTER}

In memory of Christina Gilmartin (1946-2012)

$\mathrm{W}$

HEN I wAS A child at the height of the Cold War, the press painted China in vivid primary colors-red menace, yellow peril, blue-clad masses. China was a back-burner story, however, compared to the Soviet threat, and my education through high school never touched upon it. A shift in public attention began with the 1971 China visit of the U.S. ping-pong team and Nixon's state visit in February 1972. Suddenly the mainstream U.S. press discovered beggarfree streets, healthy children, acupuncture anesthesia, and national optimism.

Like many of my college-age peers who came of age during the Vietnam War, I was compelled by the critique of U.S. imperialism and the appeal of socialist revolution that a self-confident China offered (see figure 1). And as a participant in the U.S. women's liberation movement of the 1970s, I was impressed by the Chinese state's explicit commitment to raising the status of women and leaving behind a footbound feudal past. Chinese posters showed women operating heavy construction equipment (see figure 2) and marching off (in theatrical productions, at least) to defend the nation from invaders. On my first visit to China in 1975, our group was taken to observe women militia members (see figure 3) and crews of young women repairing high-voltage wires (see figure 4). Progressive bookstores in the United States began to sell buttons with the Chinese slogan "Women Hold Up Half the Sky," a gesture of international solidarity that also served as a validation of the women's movement in the United States. For me and many others, the study of China and its modern revolutionary history offered a powerful combination of intellectual challenge, social justice, and feminist critique.

Much of what attracted me to the Chinese revolution was a fantasy-more accurately, a series of overlapping fantasies, some promulgated in China, others held by progressive political activists abroad. The Chinese revolution ran a complex course that had little to do with its status as an object of desire or a political inspiration. And the past thirty-five years of reform have only deepened the complexity, as events have repeatedly confounded expectations. In the years since we first heard the slogan "Women Hold Up Half the Sky," a rich and varied body of feminist scholarship has raised questions about what liberation did

Gail Hershatter (gbhers@ucsc.edu) is Distinguished Professor and Chair of History at the University of California, Santa Cruz. 


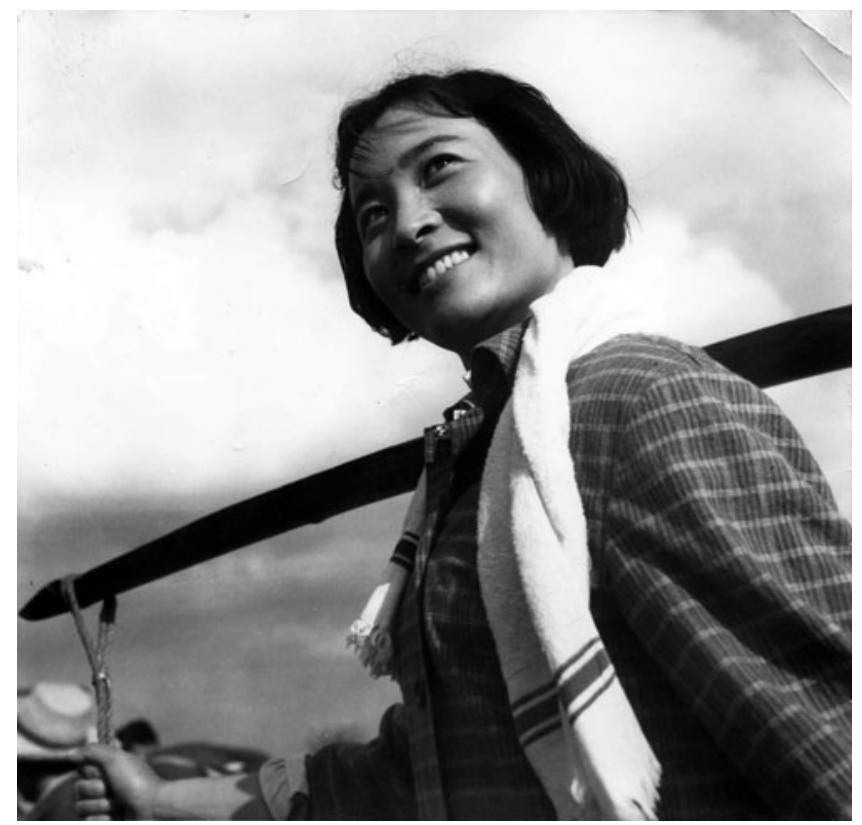

Figure 1. State-farm worker Wang Zheng playing a peasant heroine in the 1974 film A Safety Belt (一副保险 带), a film that exemplified the practice of "workers/peasants/soldiers playing workers/peasants/soldiers." She now teaches women's and gender studies at the University of Michigan. Photograph used by permission of Wang Zheng.

and did not entail. ${ }^{1}$ Moreover, it has been noted that women in China, as elsewhere, may have been holding up far more than half of the sky. ${ }^{2}$

\footnotetext{
${ }^{1}$ Buoyed by improved access to research materials in China, as well as by provocative conversations across disciplines and areas of geographic specialization, the scholarly study of gender has flourished among China scholars and among those who work on other areas of Asia. Gender, as an ensemble of fluid social and cultural practices and a language of power and political signification, has become the focus of innumerable monographs, scholarly articles, conferences, special issues of journals, and journals of its own. I spent much of the first decade of this millennium surveying only one portion of this material, on women and China's long twentieth century, first for a state-of-the-field essay in the Journal of Asian Studies (Hershatter 2004) and then for a freestanding volume (Hershatter 2007). If I were to contemplate a revised edition of that volume today, I would have to take account of hundreds of new pieces of work. The appeal of this topic and the richness and variety of the scholarship are indisputable. It is also important not to elide differences between Anglophone and Sinophone scholarship. For analysis of the different fashioning and reception of ideas about gender among Anglophone scholars and those writing in the PRC, see Gail Hershatter and Wang Zheng (2008). Articles written in or about Taiwan, Hong Kong, and other places are also shaped by particular scholarly environments.

${ }^{2}$ Similarly, the slogan "Whatever men comrades can do, women comrades can do too" establishes the activities of a male subject as the standard of achievement. On the history of this slogan, which is attributed to Mao, see Honig (2011).

"Socialism with Chinese characteristics," as it has evolved since the early 1980s and particularly in the past two decades, has certainly taught us about rapid social change, but not in the mode we
} 


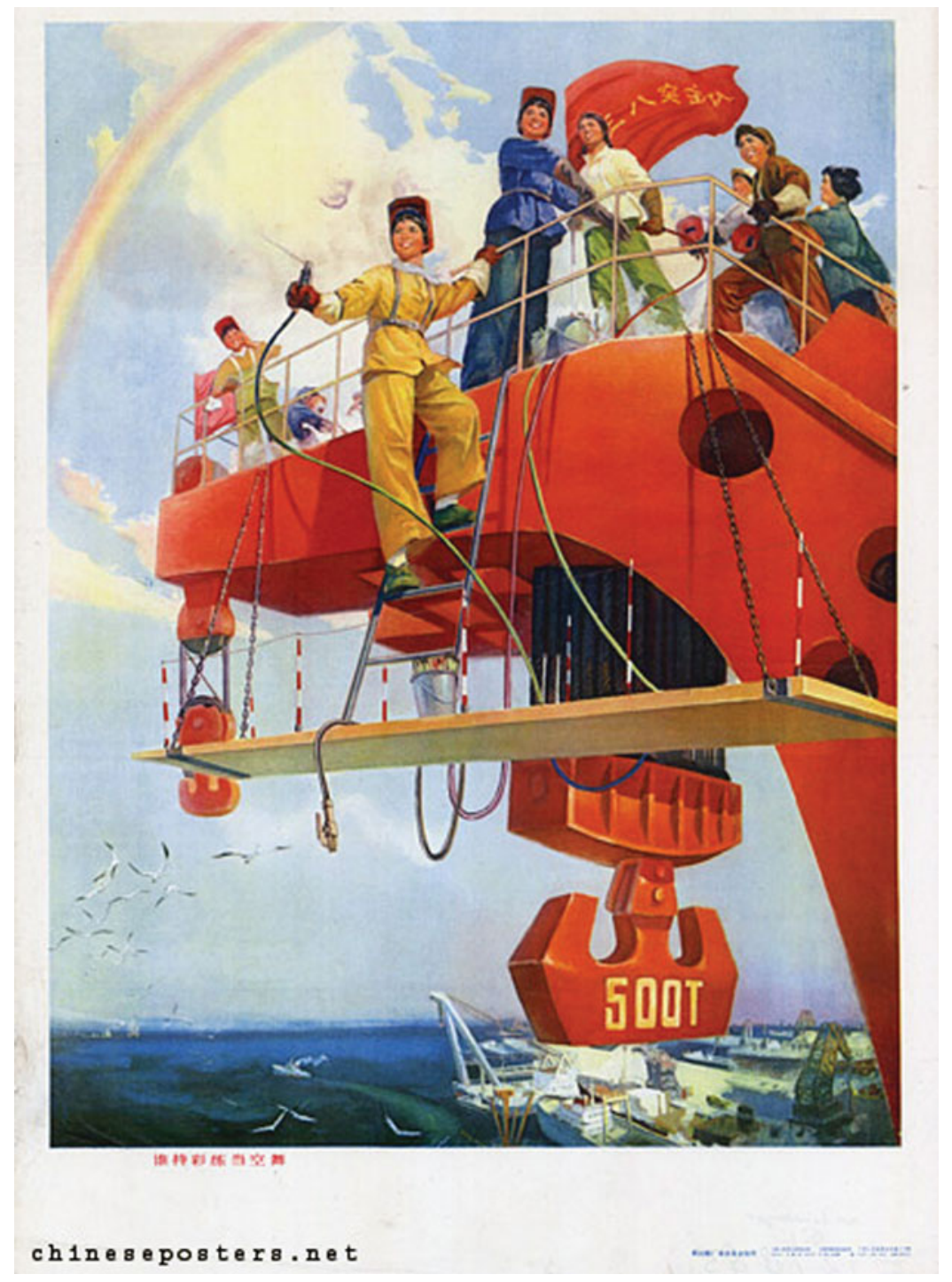

Figure 2. Those holding colored ribbons dance high in the sky, 1976. IISH/Stefan R. Landsberger Collections. http://chineseposters.net/ images/e13-885.jpg.

once found attractive. The image of heroic, empowered women holding up half the sky has been displaced by other figures, embedded in other powerful systems of signification: the sexy young mistress, the savvy woman business executive, the canny rural entrepreneur, the oppressed migrant factory laborer or sex worker. Along with the expansion of opportunities for gendered selffashioning in the reform era has come increasingly visible evidence of gender discrimination and gendered violence. As many scholars have observed, gender difference and gender hierarchy have been rediscovered as the natural order of things in official and popular realms. 

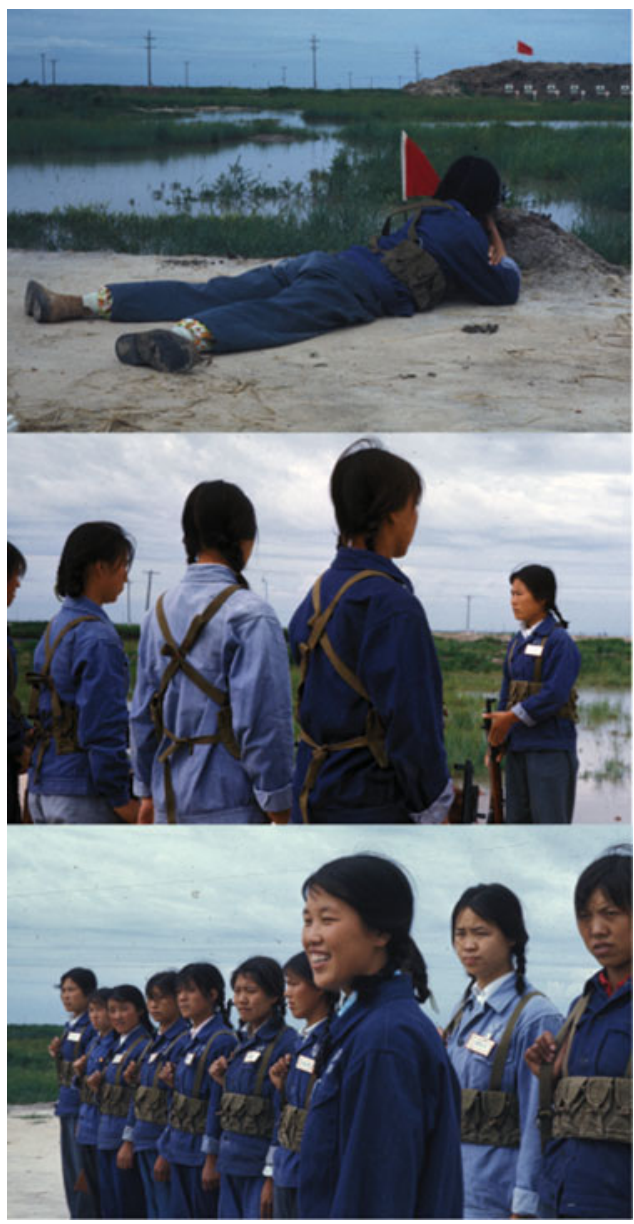

Figure 3. Women militia. Photographs by Gail Hershatter, 1975.

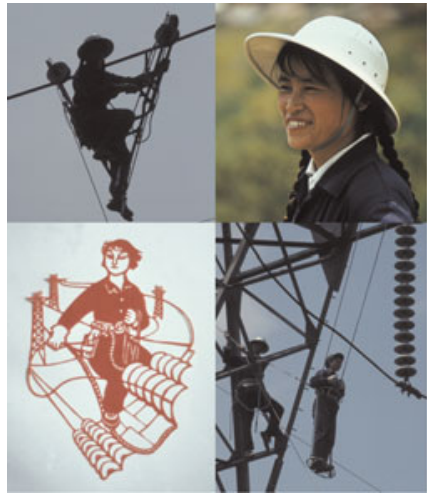

Figure 4. Women repair high-voltage wires. Photographs by Gail Hershatter, 1975. 
An older and wiser scholar is supposed to cast off the fantasy in favor of a clear-eyed, rational accounting of history. And yet fantasy is a powerful constituent of any revolution, as it opens up imaginative political possibilities. ${ }^{3}$ For scholars as well as Chinese revolutionaries, this imaginative conceptualizing-one of the definitions of fantasy-is indispensable.

And so the line of inquiry I want to explore in this essay is not about repudiation, but rather about recuperation and expansion. In her 2008 presidential address, Elizabeth Perry suggested that scholars should reclaim the Chinese revolution from the subsequent judgment that it, and other revolutions, were "a nasty and needless mistake" (Perry 2008). Perry argued, and I agree, that this work of reclamation should not replace one totalizing story of heroic revolution with another of unrelieved perfidy. Our work as area studies scholars is not to grasp and explain "China" or "the revolution" as an imagined whole. Rather, it is to ask a more adequate set of questions about what that revolution meant and to whom, and how the effect of a unified revolutionary nation (known in shorthand as "China") was created.

Once, not so long ago, it would have been revolutionary to say that gender is very helpful in analyzing the course of revolutions and the building of nations. Now such a statement is commonplace; gender is everywhere in the scholarship. We have staked a claim to territory, built a scholarly home-let's call it a houseof gendered scholarship, decorated it beautifully, remodeled and expanded it incessantly, and nurtured several generations of scholars there. We have also suggested that from this house, we enjoy excellent views of the entire neighborhood, the nation, and the world. I'm not in favor of burning down the house of gender-far from it-but in this essay I aim to introduce a bit of disquiet by suggesting that we think of gender not as a structure, but rather as a fractured, unpredictable, and expansive terrain. In doing so, we can find new and more varied lodging places for gender as a category of historical analysis.

Feminist scholars have long observed that one cannot just "add women and stir," and that serious attention to women's lives changes our understanding of the entire sweep of history. We have not been satisfied to see women talked about only on week eight of the syllabus, while the main story lumbers on. We argued that the language of gender, the naming of gendered oppression and liberation, and the mobilization of women were central to the end of the Qing dynasty, the building of the Republic, and the course of the communist revolution before and after 1949. We went to the heart of the nation, the revolution, and the activities of the post-1949 Party-state and made our case for the centrality of

${ }^{3}$ Joan Scott has argued in her recent book The Fantasy of Feminist History $(2011,21)$ that fantasy, like gender, is a useful category of historical analysis. "We have to ask," she writes, "how, under what conditions, and with what fantasies the identities of men and women-which so many historians take to be self-evident—are articulated and recognized." 
gender analysis there, where it would make the biggest impact on the grand narrative of history. (These also happened to be the parts of the story where the paper trail was thickest.) We have created a rich field-but we have also bent and shaped it to be legible in national political terms.

What is the problem here? When we tie gender to a national story or a revolutionary project — when we say that looking out from the house of gender, one can map the entire neighborhood — we may begin to assume that gendered change proceeds on revolutionary time or state time, that there is one progressive temporality marking historical change. Or we may talk about social changes as though they lag behind state initiatives in a predictable way: tradition drags on modernity, or in the terms Chinese state authorities have often used, "feudal remnants" block the path to socialism. ${ }^{4}$ But "China," as a singular entity or a uniform culture or even a clearly defined polity running on state time, is a claim, not a completed process. It is important to track state claims and initiatives, of course, as well as resistance to them. But it is also important to note when a state initiative was met with indifference or didn't register at all, and to notice the unpredictable moments when language and policies introduced by the state were refigured, appropriated, or taken up by women for surprising and unintended purposes.

The feminist historian Joan Kelly (1984) once famously asked: did women have a Renaissance? Her point was that canonical historical events always have a gendered dimension, and that what counts as an event for some may not affect or be perceived by others. Similarly, we might want to ask: did women have a Chinese revolution, distinct from that of men? (Did all men have the same Chinese revolution?) What norms and practices of gender, what modes of "being a woman" or "being a man," did the Chinese revolution produce?5 When did people think of themselves in gendered terms, and when were other modes of identification, such as family or lineage member, farmer, Party member, student, youth, or elder, more important? These questions introduce temporality and instability into categories that we normally hold constant in our scholarly work: nation, woman, man, self, politics. They enable us to ask: what counted as a revolution, for whom, and when?

Here gender retains a radical potential, one that scholars have not yet adequately deployed, to ask about where big political projects intersect, or don't, with changes in affect, desire, sense of self, and the smaller projects of everyday life. Gender expands our understanding of "the political" beyond the realm of

\footnotetext{
4"Tradition" and "feudal remnants," in Chinese state analysis and that of feminist scholars, are often understood as rural and masculinist; their presumed victims are peasant women, especially younger women.

${ }^{5}$ Joan Scott $(2011,11)$ comments: "There is no essence of womanhood (or of manhood) to provide a stable subject for our histories; there are only successive iterations of a word that doesn't have a fixed referent and so doesn't always mean the same thing. If this is true of 'women,' it is also true of 'gender.' The relationship posited between male and female, masculine and feminine, is not predictable; we cannot assume that we know in advance what it is."
} 
regime change, laws, rights, campaigns, class struggle, and mass protests. It directs us as well to daily practices, such as domestic and collective labor, and to attachments to kin, friends, and self, as sites where the political takes shape. Attention to gender shifts our understanding of the temporality and trajectory of political change, of what counts as profound transformation to, say, a rural woman. Perhaps we need to rescue a discarded slogan from second-wave feminism: "the personal is political." And, conversely, we need to pay special attention to moments when the political is personal.

Three examples drawn from my research on gender and memory in 1950s rural Shaanxi may help us imagine an expanded notion of political change (see figure 5). The situations I am about to describe are found in my 2011 book The Gender of Memory: Rural Women and China's Collective Past, ${ }^{6}$ but my observations about these stories are not. I offer here an extended set of afterthoughts about how and when certain actions, emotions, and attachments became thinkable to rural women, and what kind of revolution that thinkability made possible.

The first story concerns a Shaanxi woman named Zhang Chaofeng. ${ }^{7}$ Born in 1934, Chaofeng was a "child raised to be a daughter-in-law," sent to the

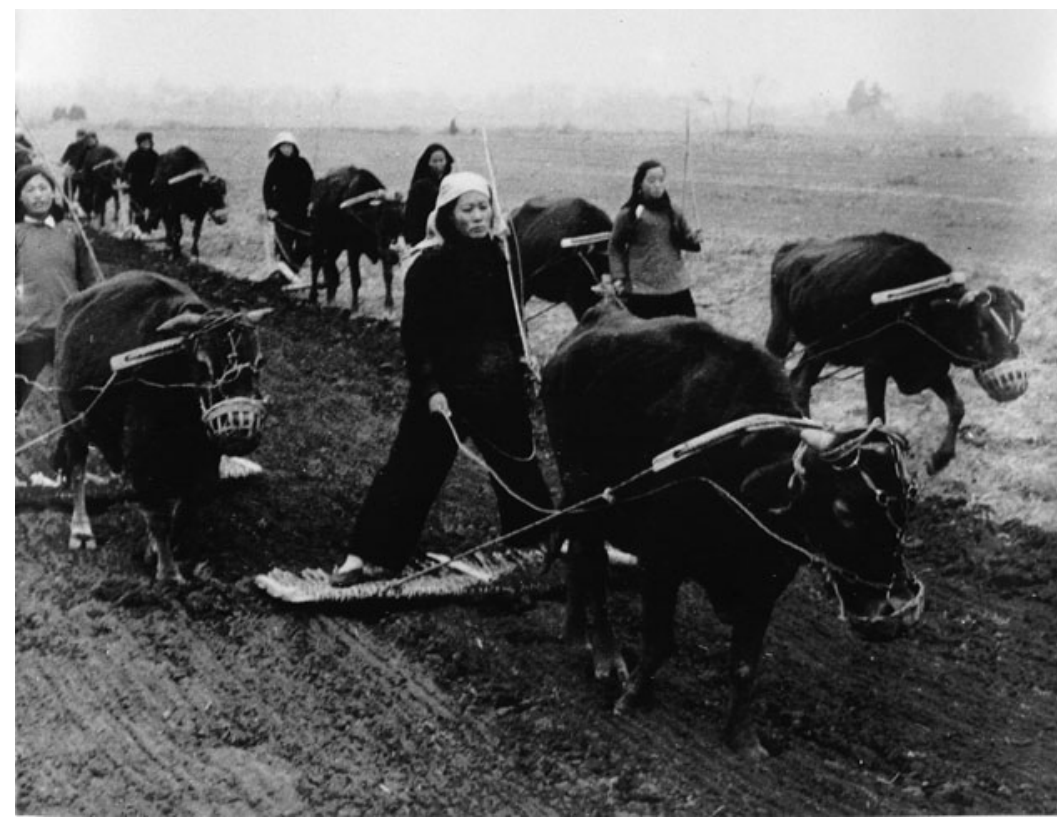

Figure 5. Shaanxi women learn farming skills, 1959. Personal collection of Gao Xiaoxian. Used by permission.

\footnotetext{
${ }^{6}$ Hershatter (2011). Much of the research for this book was conducted jointly with Gao Xiaoxian. Details about her work and her plans for using this material are given in the book.

${ }^{7}$ The name is a pseudonym.
} 
family of her future husband at the age of eight and married at thirteen. She doesn't remember any details about the change of government in 1949, or the announcement of the Marriage Law in 1950, which mandated an end to arranged marriage and outlawed child betrothals. Yet over the course of a decade, the rural policy initiatives of the new Party-state did change her life. She learned to read and write, became a cadre responsible for mobilizing women to tend the collective fields, and joined the Communist Party. Still, she remembers thinking in 1955 that the Marriage Law was for others, not for people like her who were (as she put it) "born in the old society."

Chaofeng's main emotional attachment was to her mother-in-law, who, in effect, had also been her mother after the age of eight. Chaofeng's husband was fourteen years her senior and mostly worked away from home. The marriage did not produce children, and Chaofeng was sure she was fertile and that the problem lay with him. Her husband wanted to adopt, and she refused; she wanted a medical evaluation, and he refused. They fought. He threw a stool and hit her in the head.

Ten years after the Marriage Law went into effect, it began to take on personal resonance for Chaofeng: "I studied about implementing the Marriage Law. I felt in order to liberate others, I had to liberate myself first." She made the decision to divorce, drawing upon the skills, contacts, and modes of selfperception that the Party-state had enabled. Now literate, she wrote a letter initiating the divorce proceeding. She got no support from her network of women's cadres, the village Party secretary, or the commune court - they feared that her divorce might compromise the local prestige of the Party-state. But her work had brought her into contact with people farther away in the county seat, and it was much safer in physical and sexual terms than it had been a decade earlier for a woman to travel there alone. She hitched a ride on a truck and filed her petition. Half a year later, she got her divorce.

The costs were high. Chaofeng was pained by the separation from her mother-in-law. She was upset by local gossip that accused her of abandoning the old woman and developing outsized ambitions as a cadre. Since her marriage, like most rural marriages, was virilocal, she had to leave the village that had been her home since the age of eight. She also lost her status as an activist and a cadre. Later she remarried and followed her new husband to a faraway city, where she raised four children and never worked as a cadre again. After the 1950s, it becomes more difficult to discern moments when her individual story intersects with the big story of Party-state initiatives.

As I thought about Chaofeng's life, something continued to puzzle me. When Chaofeng first encountered the Marriage Law, why did it seem irrelevant to her? How did she subsequently come to understand herself as incited to action by it, in spite of a deep attachment to her mother-in-law and a desire to be regarded in the community as someone who behaved in a filial manner to the woman who had raised her? 
One can understand Chaofeng's divorce as a story of delayed response. The state promulgates a Marriage Law in 1950; cadres propagandize it; village authorities resist, as do many family elders; young people become aware of the law unevenly, depending on the depth and robustness of local feudal remnants. ${ }^{8}$ Gradually, some people begin to understand the law as being addressed to them-in Louis Althusser's terms, they respond to being "hailed" by the state, and enter into a particular relationship with it (Althusser 1971, 174). And so progress gradually takes hold, as one individual at a time disentangles from family control over marriage and reconceives it as an individual or conjugal decision sanctioned by state authority. A backward rural sector gradually accepts and owns new practices about marriage and family-practices consistent with the mobilization of women for collective farm work and their participation in local leadership.

This explanation reinscribes a notion of the political that is framed and determined by an expansive state. The notion of a delayed response fails to capture a certain messiness, one dear to historians. State initiatives that land in a complex landscape may be ignored or resisted, but then they may articulate in unexpected ways with preexisting customs, practices, and emotional dispositions. And the landscape itself is always changing, not always as state authorities might hope or intend.

Since we're in the house of gender, and also the household of Chaofeng, I want to suggest that we instead think of a big state initiative, such as the Marriage Law (or even a revolution), as similar to plunking down a strange new appliance in a household, without asking whether it will be fully usable or will be put to use as intended. My colleague Wlad Godzich tells just such a story about this object (see figure 6), an oil lamp made in a village in Ghana in the early 1980s (Godzich 2002). Under the African socialist plans of Kwame Nkrumah, the village was scheduled to get electricity during the 1960s. But Nkrumah was deposed in a coup in 1966, and for that and various other reasons having to do with the International Monetary Fund and structural adjustment, the villagers found themselves still without electricity in the 1980s. Meanwhile, as Godzich comments, "one northern country had delivered to them a large quantity of lightbulbs" in

\footnotetext{
${ }^{8}$ The fine work of many scholars helped me understand the Marriage Law campaign and the complex local responses to it. In books published in the 1980s, Kay Ann Johnson (1983) and Judith Stacey (1983) discussed the fear of local cadres and family elders that the Marriage Law would cause the loss of wives who had been expensive to acquire, the disadvantaging of poor men, and general local mayhem. Margery Wolf's Revolution Postponed (1985) made it clear that more generally, whenever gender equality threatened class solidarity or patriarchal village norms, the Communist Party was willing to defer dealing with gender issues. And we know from Neil Diamant's 2000 revisionist analysis of the Marriage Law that in spite of official opposition centrally and locally, peasant women nonetheless assiduously pursued divorce, often marching off to more distant jurisdictions, just as Chaofeng had done.
} 


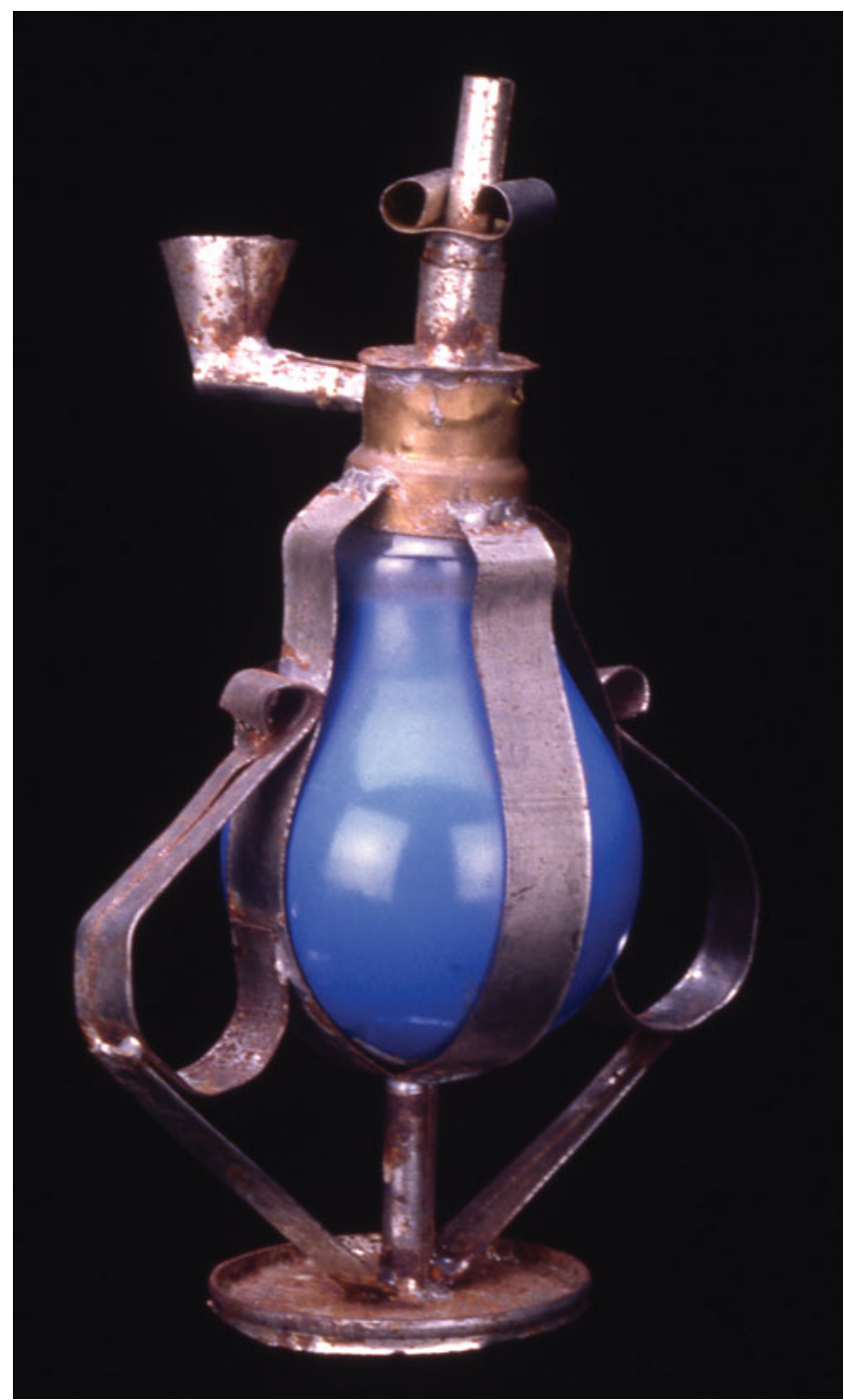

Figure 6. Oil lamp made from an electric light bulb and tin can, Kumase, Ghana. (OThe Trustees of the British Museum.

anticipation of an electrification project that was now on indefinite hold (Godzich 2002). The lightbulbs sat around for awhile. Then the villagers-needing lightremoved the metal base and filaments from the lightbulbs, let the inert gas out, filled the lightbulbs with kerosene or another fuel oil, fashioned a base out of Coke or beer cans discarded by the various experts and government officials who had visited the villages, and produced usable lamps.

What does this tale of a lamp give us that the story of developmental delay and catching up leaves out? A state initiative-an electrification plan complete with lightbulbs, or a Marriage Law_arrives on the landscape. The household's 
inhabitants may look at it with puzzlement, or not look at it at all, but it becomes an increasingly familiar part of their environment. Then one day they see a use for it, pick it up, and refashion it. The original cannot always be deployed as intended (there's no electricity; the local cadres are unenthusiastic about divorce and implementing the law). But people exercise a certain agency, piecing together whatever is available, in the name of a local or even an individual agenda, without necessarily seeing or being concerned about the whole. An end is achieved-household light, a divorce-but not exactly as the state intended. The villagers get light, but it is not as uniform or predictable or externalized as the light of electrification. They get-really, they make-something usable in the actually existing present. Similarly, Chaofeng gets a divorce, even though the state was an uneven and unreliable partner in implementing its own law. But her emergence from a child daughter-in-law marriage does not free her, as the Marriage Law intended, to be mobilized further for collective labor and active citizenship. She never became a fully mobilized state subject because the divorce process effectively removed her from the village where she had been carefully cultivated as a local leader, sending her back into the status of household dependent in a new community. But the divorce did shed some light or clear some ground, enabling her to start a family under conditions of her own choosing.

An important question in assessing the effective reach of a revolution, then, is to ask (figuratively speaking) how and why the inhabitants begin to desire a lamp, to imagine themselves in a house where lamps are normal rather than superfluous or unthinkable. ${ }^{9}$ The Marriage Law, and the hours of work Women's Federation cadres put in over the years to promote it, are part of what made change in Chaofeng's village imaginable. But it is equally important to ask about the moment when Chaofeng came to feel that the law was addressing her, a woman "born in the old society" and effectively raised by her mother-in-law. In Chaofeng's telling, the environment in which she had come of age no longer seemed tolerable. The affective costs of staying in a difficult marriage began to outweigh the emotional, political, and community effects of leaving it. A divorce became thinkable. This was a process with many dimensions: psychic, developmental, social, sexual, affective, and political. The Marriage Law provided a language and a set of procedures: crucial components. But making something

\footnotetext{
${ }^{9}$ In a recent paper about 1950s China, Neil Diamant (2011) discusses policy osmosis, which he defines "as the process by which experience from one policy and campaign shaped the interpretation of those subsequent to it, usually in ways contrary to the government's intentions." He documents the ways that language and practices from the land reform campaign seeped into enforcement of the Marriage Law, resulting in inappropriate targeting of "feudal" elders and fear on the part of cadres that any campaign could become the occasion for career-damaging mistakes. Seepage from one campaign to another is worthy of further thought, but so is seepage from one domain to another-e.g. from the law and political meetings to a young woman's affective ties and sense of possibilities (Diamant 2011).
} 
usable out of the law and other available pieces was Chaofeng's doing. An expanded notion of the political emerges from the events she set in motion and the larger community scene in which they unfolded.

My second example does not center on a specific individual. It is about food, compassion, and care in rural households, all domains in which women are the dominant actors. I will put the conclusion first: changes set in motion by rural collectivization in the Mao years slowly changed community expectations of obligation, virtue, and attachment, particularly the role of the daughter-in-law in elder care, producing what has now become an unforeseen crisis of elder neglect afflicting countless rural communities.

How did this come about? Before collectivization, one or more married sons typically remained under the same roof as their parents, with all the able-bodied adults pooling labor and resources, and the daughters-in-law assuming increasing responsibility for household management as their in-laws aged. When a father died, land was divided among surviving sons. During the Mao years, collectivization eliminated private landownership, although families continued to pass their houses on to their sons. Meanwhile, families grew, as more children survived infancy because of the end of warfare, relative political stability, and improvements in public health. With both men and women working in the collective fields, grandparents, especially grandmothers, bore an increasing burden of domestic work (see figure 7), and whatever work points the elders earned went to feed expanding broods of grandchildren. In order to shield themselves from the consequences of growing families, stagnating household incomes, and unacknowledged, unremunerated labor, the senior generation often initiated a formal household division, creating a separate household for collective accounting purposes and the distribution of work points and grain. This did not mean that elders

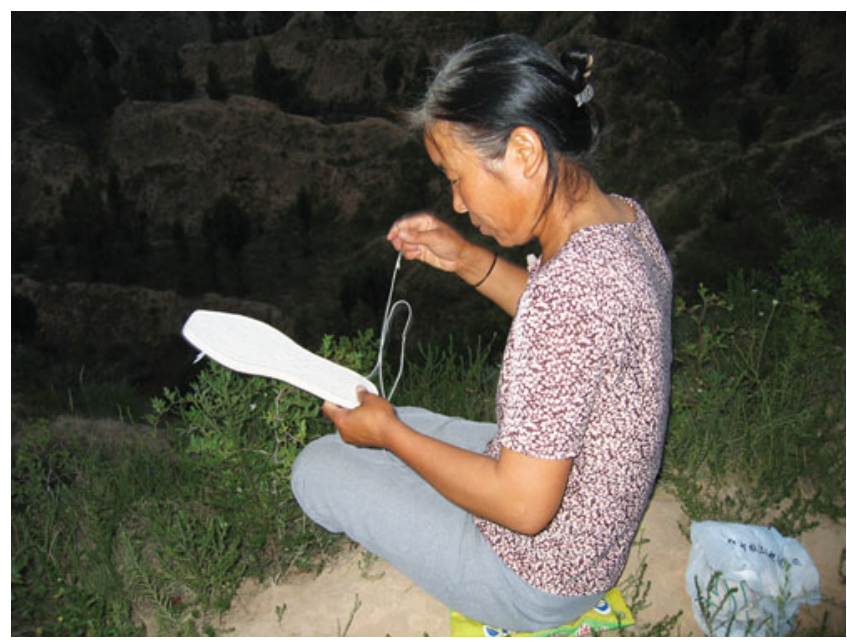

Figure 7. Woman sewing, Shaanxi Province. Photograph by Gail Hershatter, 2004. 
cast out their grandchildren. If food was short, often a paternal grandmother would call the grandchildren over to eat. But by dividing households, older farmers encouraged their sons and daughters-in-law to carry more of the burden of supporting their own children.

Household division was never a state goal. For most of the Mao years, state planners were not trying to reconfigure households. (The policies of the Great Leap Forward were a brief and disastrous exception.) From the state's vantage point, kinfolk were exhorted to dwell together harmoniously, perform the invisible (mainly female) labor of feeding and clothing and raising the young, and emerge each day to work energetically in the collective fields. Nevertheless, the state push for collectivization, aimed at increasing agricultural production and extraction, meant less intergenerational transmission of property, reliance on collective work points for support, and changing patterns of household division.

By the 1980s, when the household became the officially sanctioned unit of farm production, people's notion of what a household should be had fundamentally changed. Now it was common in many rural areas for sons to separate households at the time of marriage. Prospective daughters-in-law no longer expected to spend their early married years working out an intimate daily relationship with a mother-in-law, and performing this role well was no longer essential to younger women's definition of personal virtue.

As the reform era unfolded, new prosperity, the chance to migrate to cities for work, and the stoking of consumer desires rapidly altered visions of the good life and introduced a profound generation gap into rural households. Many young women and men left the countryside. Meanwhile, as the minimal economic guarantees provided by the collective disappeared and competition increased, middle-aged farmers faced the need to support their aging parents, who as a group were living longer than ever. The Constitution still mandated that grown children must care for their parents, and the Party-state exhorted households to provide a social security net for the aged. But the survival of multiple sons into adulthood weakened the sense of responsibility felt by any given son, introducing fraternal conflicts over who should contribute what to the care of elderly parents.

This is, in several respects, a gendered crisis. On average, women live longer than men in the Chinese countryside, and the majority of those affected are aging women. Traces of earlier norms remain: often neighbors will talk about a neglected or abused elder by evaluating which of the daughters-in-law has shirked her duties. Older women themselves see the daughter-in-law as the linchpin in a filial mechanism gone awry. As one woman put it, "Nowadays, the daughter-in-law has turned things upside down. The mother-in-law is the daughter-in-law, and the daughter-in-law is the mother-in-law. You work for her." This mode of talking about care of the aged attests to the cultural durability and state endorsement of a model of womanly virtue. But these very words might 
well have been uttered fifty years ago, during the collective era, by an older woman contemplating the burden of feeding and caring for grandchildren. The collective, in its move to intensify extraction of resources from agriculture by drawing women's labor out of peasant households, inadvertently produced several generations of farming women who no longer saw the multigenerational household as a desirable arrangement.

I am not making a nostalgic or revanchist argument for the households of yore, marked by hierarchies of gender and generation with young women at the bottom of both. Rather, the point here is that households worked out their own adaptive strategies within a matrix provided by collectivization, changing the larger community in unanticipated ways. To understand how the political became personal in rural socialism, we must track the connections between policy, everyday domestic labor, inheritance, longevity, and the entrenchment of new notions about what it means to live well and behave as a proper wife, mother, son, or daughter-in-law. Gender is at the heart of the matter.

My final example of the complex entanglement between gender and the political concerns the birth planning policy in effect since the early 1980s. Often called the "one-child policy," in rural areas it has in practice been a two-child policy if the first child is a girl. Very good scholarship has been produced about the origins of this policy, the local conflicts it engendered, and the shifting course of implementation efforts. ${ }^{10}$ The conflict has usually been characterized as one between "the state"-at top levels, but represented most directly by local cadres—and "the people"-including, of course, women.

But in the case of the birth planning policy, women had complex loyalties and investments - they were both "the state" and "the people." The face of birth planning enforcement in many villages was that of a middle-aged woman cadre. She was charged with visiting village families, discovering over-quota pregnancies, convincing women and their husbands and in-laws to terminate such pregnancies, accompanying pregnant women to and from the county seat for the procedure, and tending in maternal fashion to their physical and emotional needs afterwards. Middle-aged women were both enforcers of the birth planning policy and dispensers of care. On the face of it, they were the perfect local agents of the state. But their reasons for supporting the policy were not identical

\footnotetext{
${ }^{10}$ Many scholars have commented on the fact that a rural reform policy making the household the major economic unit, and the need for farmers to depend upon their grown able-bodied children for old-age support, were inducing farmers to maximize their production of children just as the state set out to minimize it. State authorities failed to foresee some of the consequences of their policy, but in practice they have been neither monolithic nor impervious to public pressure. Scholarship has also traced the many changes, loosenings, tightenings, and local variations in enforcement of the policy. When state authorities met resistance, they first responded with the same kind of "feudal remnants" thinking they had employed to describe resistance to the Marriage Law three decades earlier, blaming backward peasant thinking for the popular response. For a brief survey of the scholarship, see Hershatter (2007, 26-36); on the origins of the policy, see also Greenhalgh (2008).
} 
to those of central state authorities, who were mainly concerned with population growth as a drag on economic development. For middle-aged rural women, support for the birth planning policy can be understood as an implicit critique of the state's gender policies in the first three decades of the People's Republic.

Many of these women had been local village activists in the 1950s: attending meetings, reading simple texts, speaking in public, and leading groups of women to labor in the collective fields. In these respects, they supported the national project of socialist construction. But then, these young women began to have children (see figure 8). They reared those children in the 1950s and 60s and $70 \mathrm{~s}$, working in the fields for work points most of the day and staying up at

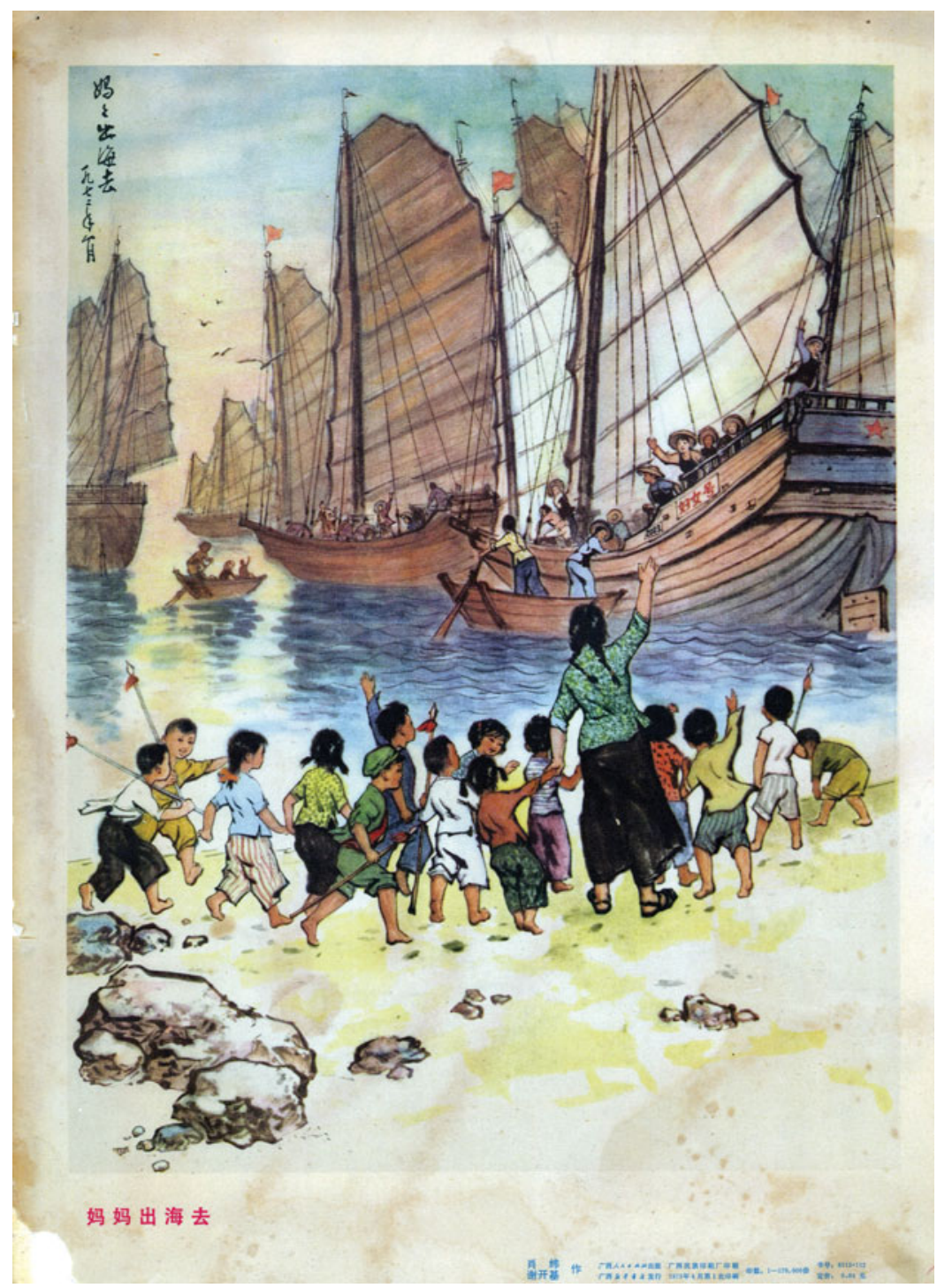

Figure 8. Mama is going to sea, 1973. Personal collection of Gail Hershatter. 
night to sew clothing and make shoes by lamplight for their growing families. During their childbearing and childrearing years, the state was virtually silent about the burden of incessant labor this situation created for women, and as I have already noted, children did not bring clear economic advantages under the collective. This generation of women spent most of their adult lives in a state of exhaustion. Some openly faulted the state for not paying more and earlier attention to birth planning. To them, the birth planning policy of the 1980s represented long overdue attention to an unrecognized site of their labor and effort. Yes, they thought that the policy was good for the nationbut the enthusiasm with which they enforced it grew out of their own lived circumstances, not abstract loyalty to a development strategy.

In 1980s rural villages, gendered desires about family size fractured along generational lines. The younger women who were the targets of the policy were beginning to bear children just as more economic initiative and responsibility were being transferred to individual households. Like the older women, they also understood domestic labor and childrearing to be primarily women's work. But they differed from the older cohort in frame of reference, political experiences, level of material well-being, emotional attachments, and notions of a desirable family formation. They did not desire unlimited family size-some mentioned a son for old-age support and a daughter for emotional sustenance - but they had very different ideas from their elders about the appropriate reach of state control and about what number of children might give them access to security and fulfillment. Shared gender, here, meant much less than generational cohort and relationship to village authorities. ${ }^{11}$

Gender is not a sufficient tool for analyzing this situation, but the situation is not legible without it, either. Gender is variable, historically inflected, and linked in uneven ways to the experiences of childbearing, mothering, and the burdens of domestic labor at particular moments. Attention to gender provides a set of questions, but cannot prefigure answers. Close attention to changing gendered dynamics also furnishes a critique of a teleological notion of how a demographic transition is "supposed" to happen, wherein rising living standards produce a predictable change in family structure conventionally associated with modernization. Both of the generations of women I have just described here can be considered "modern," but they had discrepant desires and notions of what modernity entails. ${ }^{12}$ Many in the younger generation deeply resented the state's regulation of birth planning. Many in the older generation resented the fact that it had not come soon enough for them. These contrasting attitudes are an indispensable

\footnotetext{
${ }^{11}$ The generational division was not absolute, of course. Many older women staunchly opposed the birth planning policy, helped their daughters-in-law to hide unsanctioned pregnancies, and harangued or ignored middle-age birth planning workers. Here the utilitarian need for old-age support, as well as deeply felt desires about what counts as happiness and a fulfilled old age were at play.

${ }^{12}$ On discrepant projects of modernity, see Rofel (1999).
} 
part of how we should understand political change_-at both the level of policy and the more intimate level of reproductive decisions.

Like other historians of modern China, in the fourth decade of the post-Mao reform era I have been asking: what was that revolution? Who made it, who benefited from it, how was it understood at the time, what is its legacy in material and social practices, how does it linger or get reconfigured in contemporary memories and understandings? Gender is particularly useful because the social processes that give it form are found everywhere: in the realms of the psyche, affect, sexuality, kinship, the local, regional, national, transnational, and so forth. And each of these realms is also shaped in part by gender. Of course, gender is not the only social process that can be found in multiple domains (Scott 1986, 1069). Class, ethnicity, and the interaction of humans with the broader environment are also crucial realms for exploration. But for the period of modern Chinese history, class analysis has been both overdetermined and undermined by official discourse. Ethnicity has been kept literally and figuratively at the margins of the Chinese state. Environmental concerns are just beginning to garner attention. Gender, central both to state initiatives and to areas unaddressed by the state, offers an unusually productive mode of analyzing how different domains of human emotion, activity, and belief articulate with one another, or don't. The Chinese revolution cannot be understood simply as a product of Party line, Party-state initiatives, intra-Party struggle, or even interactions between Party and non-Party actors. To understand what that revolution was or was not, and to whom, we need to scale up and down, looking for points of articulation, friction, and disconnection between these various domains.

For people familiar with classical Chinese writings, using gender as a kind of lens that allows one to zoom in and out at first sounds like an activity Confucius might have endorsed. The Great Learning, a text that Theodore de Bary tells us was attributed to disciples of Confucius, though perhaps written several centuries later, was memorized by every educated boy and was required knowledge for the civil service examinations throughout the late imperial period. It names the family as an essential link in the construction of social order, as follows: "The ancients who wished clearly to exemplify illustrious virtue throughout the world would first set up good government in their states. Wishing to govern well their states, they would first regulate their families. . . . Only when our persons are cultivated are our families regulated; only when families are regulated are states well governed; and only when states are well governed is there peace in the world. . .." (de Bary, Chan, and Watson 1960, 14-16). ${ }^{13}$

\footnotetext{
${ }^{13}$ The text continues (16): "If one family exemplifies humanity, humanity will abound in the whole country. If one family exemplifies courtesy, courtesy will abound in the whole country. . . . Thus we see why it is that 'the government of the state depends on the regulation of the family."
} 
A corollary theme in classical writings assigns women a central role in personally embodying virtue, in teaching their sons the virtues required of a good ruler, and in counseling powerful husbands on how to handle perilous or difficult situations. Susan Mann (1997, 28-29, 239n48) quotes Qing magistrate Lan Dingyuan in his book Women's Learning: "The basis of the government of the empire lies in the habits of the people. The correctness of the habits of the people depends upon the orderly management of the family. The Way (Dao) for the orderly management of the family begins with women." 14

In the twentieth century, both the Nationalist and the Communist states exhorted women to modernize the home in order to build a strong nation. Women were encouraged to transfer their performance of loyalty from the family to the state, or more specifically for rural women in the Mao years, to transfer their service from the mother-in-law to the production team. The idea that one can scale up and down from the familial performance of gendered normative behavior to the state has a long genealogy in Chinese political thoughtand a more recent evocative history in Chinese political campaigns.

But here an important caveat is in order. Gender-what it means in public discussion, how it is understood by the people it classifies-is fragmented, discontinuous, and historically contingent. All of the domains I have been discussing (affective, psychic, normative, household, community, state) are porous and entangled. They are not neatly nested inside one another. One cannot use the design feature known as "scalability," in which, as Anna Tsing puts it, "small projects can become big without changing the nature of the project" (Tsing 2012). In the world of social processes such as gender, changes in one realm do not automatically ramify in a coherent or predictable way in the other. For Chaofeng, a divorce became thinkable years after the Marriage Law and political campaigns to promote it, in tandem with her coming of age and other highly individual factors. In the case of collapsing elder care, a state initiative to collectivize agriculture with households as the necessary support structure undermined those very households, with collateral damage to practices of filial obligation and womanly virtue. The state's birth planning goals received unexpected support from a generation of women who felt shortchanged and exhausted because of earlier state neglect. Each of these instances necessarily enlarges our understanding of what counts as political. Of course, in reform-era China, shrinking the space of the political-depoliticization—has been a project enthusiastically taken up by state authorities and local populations alike (Wang 2009). But this

\footnotetext{
${ }^{14}$ Mann (1997, 223) further notes: "[T]he history of gender relations in the High Qing era shows clearly that in Chinese culture at that time, women's homely place in elite public discourse was recognized and articulated by leading intellectuals, as when the philosopher Zhang Xuecheng acknowledged the dependence of public man on cloistered woman by noting that her words, too, could be 'everyone's' (gong). . . . In short, the historical record of Chinese women-both their placement in it and their consciousness as recorded there-shows a pervasive awareness of the intimate relationship between family life and public politics."
} 
does not mean that communities are less fraught with conflict, class tensions are absent, abuses of power have diminished, or social justice has been achieved. We can only reclaim, and adequately analyze, the realm of the political if we consciously enlarge our awareness of how and where it takes shape.

Perhaps the point is not to scale up and down, but rather to pay attention to what Anna Tsing calls nonscalability ${ }^{15}$ - a concept that allows us, as she puts it, to tell big stories alongside small ones, without assuming that the only difference is in scale (Tsing 2012). Gender is useful here, not because it can be pinpointed and mapped as a self-same thing at the scale of the psyche or the nation, but because it is multi-scalar rather than scalable. We must learn to think about fragmented, partially articulated scales of analysis: person, household, community, region, nation, and beyond. Their articulation, full of lumps and gaps, constitutes the realm of the political. Gender suggests a set of questions we can use to understand the constantly realigning relationships among these levels.

I titled this essay "Disquiet in the House of Gender" because I wanted to signal a certain uneasiness with the claim we feminist scholars have made: that gender is central to the fate of the nation and the course of the revolutionnot because this claim is too big, but because it can confine us to a restrictive notion of what counts as political. In zooming in and out from the household to the state, we have often assumed isomorphisms ${ }^{16}$ and linkages, relied upon stable meanings of gender across domains, and explained incongruities as instances of developmental delay. I am still indebted to the insight that gender, as a process, is everywhere. But it is not always the self-same thing wherever it is found. We need a mode of investigating gender that takes better account of frictions, gaps, and incommensurabilities.

The house of gendered scholarship, like other houses, has been characterized by deep relationships and shared language, by divisions of labor and squabbling, by conversations and mutual support. But a house has the disadvantage of being enclosed even if it provides partial views of the surrounding environment. Nor am I recommending that we think of gender as a commanding promontory from which we can survey the world-too much fine-grained detail will become invisible. Perhaps gender could be thought of instead as an anchoring foothold or handhold, something like the spring-loaded camming device rock climbers use to scale an unfamiliar rock face (see figure 9). A cam can be placed in a crevice, without damaging the rock, and used to anchor a rope.

\footnotetext{
${ }^{15}$ Tsing (2012) writes: "Nonscalability theory allows scales to arise from the relationships that inform a particular project, scene, or event. . . In this work, there are big stories as well as small ones to tell. There is no requirement that the scales nest or that one can perform the wizardry of conversion from one to the other without distortion. . . B Because relationships are encounters across difference, they have a quality of indeterminacy. Relationships are transformative, and one is not sure of the outcome. Thus nonscalability theory requires attention to historical contingency, unexpected conjuncture, and the ways contact across difference can produce new agendas."

${ }^{16}$ For a recent critique of the effects of this isomorphism as a political ideal, see Shih (2010).
} 


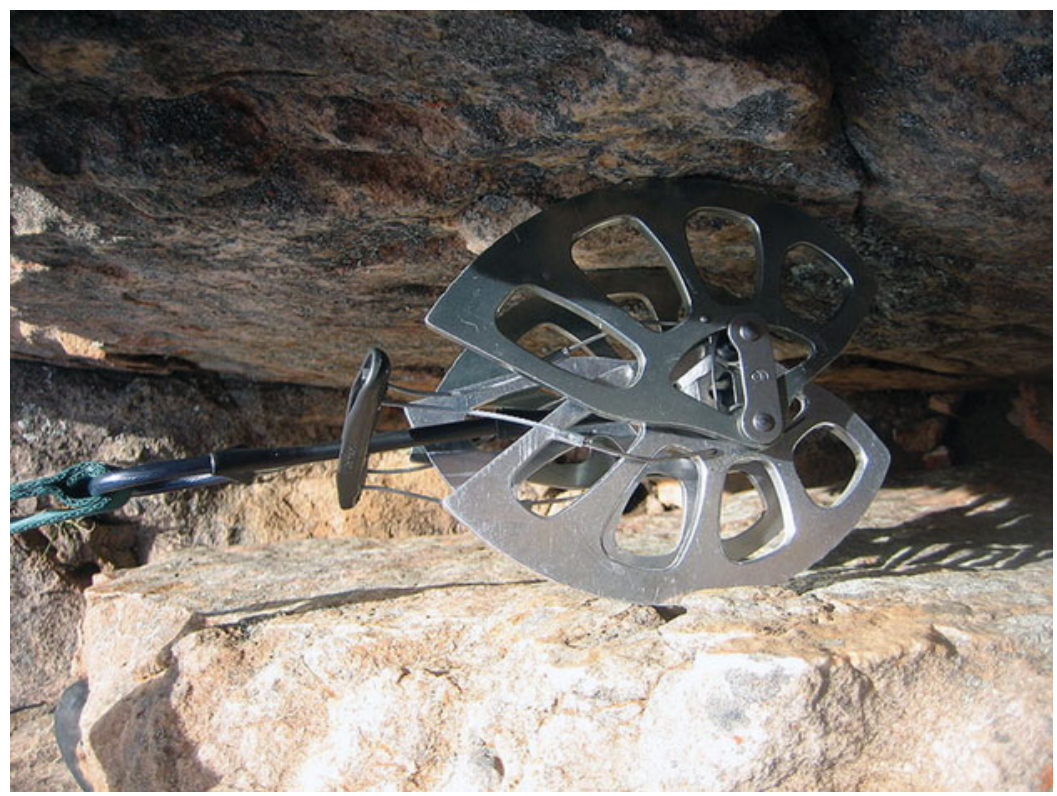

Figure 9. Spring-loaded camming device. Burtonpe at en.wikipedia. http://en.wikipedia.org/wiki/File:Camalot_number_6.JPG.

Such a tool doesn't predict the shape of the rock face or tell you what outcropping is coming up next. It is, however, a way to anchor yourself, hanging on for dear life, while you figure out, one specific step at a time, the best way to traverse the rock face to the next fissure, which may or may not be connected to the one that currently supports you (see figure 10).

So perhaps we need to get out of the house. Disquiet in the house of gender has the salutary effect of propelling us into the wider world, where we cannot depend upon isomorphism between family and state, assume stable linkages across domains, or sit back and enjoy the view from a single well-appointed location. Nurtured and tempered in the house of gender, we are better equipped to navigate this expanded terrain.

\section{AcKNowledgments}

Once again, I thank Gao Xiaoxian for the opportunity to work with and learn from her during the fifteen years of research and conversation that shaped The Gender of Memory. Wlad Godzich first brought the story of the oil lamp to my attention. A host of friends and colleagues read this essay in draft, offering encouragement and suggestions: Noriko Aso, Wendy Brown, Alan Christy, James Clifford, Emily Honig, Minghui Hu, Su-kyoung Hwang, Susan Mann, Lisa Rofel, Randall Stross, Anna Tsing, and Alice Yang. Judith Butler listened to my ruminations and helped me devise a title. Thanks also to Charlotte Furth, Joan Judge, Dorothy Ko, and Wang Zheng for ongoing discussions over 


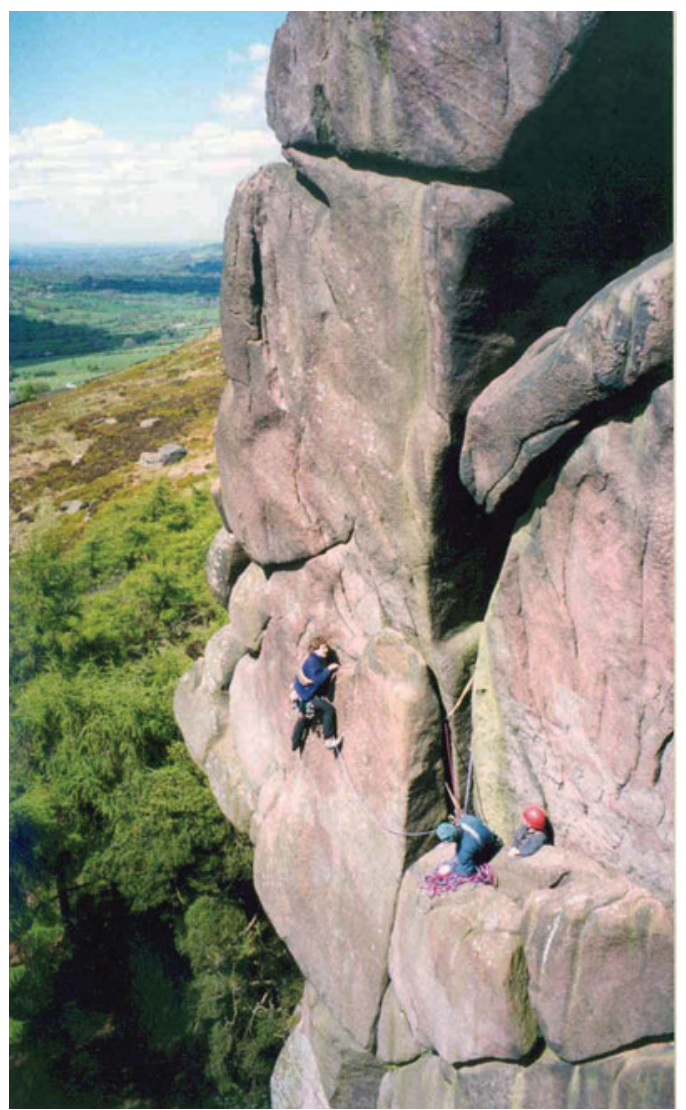

Figure 10. Climbers on "Valkyrie" at The Roaches in Staffordshire, United Kingdom, in May 2002. English Wikipedia, May 5, 2002. http://en.wikipedia.org/wiki/File:Valkyrie_\% 28The_Roaches\%29.jpg.

many years, and to K. Sivaramakrishnan for his lovely introduction to the talk that became this essay. The late Christina Gilmartin, to whom this essay is dedicated, was a tireless supporter of my work and that of many other scholars; I miss her warmth and wise counsel.

\section{List of References}

Althusser, Louis. "Ideology and Ideological State Apparatuses," in Lenin and Philosophy and Other Essays. New York and London: Monthly Review Press, 1971.

de Bary, Wm. Theodore, Wing-Tsit Chan, and Burton Watson, comp. With contributions by Yi-pao Mei and others. 1960. Sources of Chinese Tradition. New York: Columbia University Press.

Diamant, Neil J. 2000. Revolutionizing the Family: Politics, Love, and Divorce in Urban and Rural China, 1949-1968. Berkeley: University of California Press. 
2011. "Policy Interpretation through Osmosis: The Impact of Simultaneity on Local Understandings of National Initiatives in Early 1950s China." Paper presented at conference on “Chinese Society and Culture in the 1950s" [“1950 年代的中国社会文 化”学术研讨会], Huadong University, Shanghai, July 1-2.

GodzICH, WLAD. 2002. "Taking Lanterns for Bladders: Symbolic and Material Appropriation in the Postmodern." In Waste-site Stories: The Recycling of Memory, eds. Brian Neville and Johanne Villeneuve, 153-64. Albany: State University of New York Press.

Greenhalgh, Susan. 2008. Just One Child: Science and Policy in Deng's China. Berkeley: University of California Press.

Hershatter, Gail. 2004. "State of the Field: Women in China's Long Twentieth Century." Journal of Asian Studies 63(4):991-1065.

- 2007. Women in China's Long Twentieth Century. University of California Global, Area, and International Archive. http://escholarship.org/uc/item/12h450zf. Print ed. Berkeley and Los Angeles: University of California Press.

—. 2011. The Gender of Memory: Rural Women and China's Collective Past. Berkeley and Los Angeles: University of California Press.

Hershatter, Gail, and Wang Zheng. 2008. "Chinese History: A Useful Category of Gender Analysis." The American Historical Review 113(5):1404-21.

Honig, Emily. 2011. "The Life of a Slogan: Maoism, Gender, and the Cultural Revolution." In Transformations: Gender and Chinese History, ed. Beverly Bossler and Ellen Widmer, in preparation.

Johnson, Kay Ann. 1983. Women, the Family and Peasant Revolution in China. Chicago and London: University of Chicago Press.

Kelly, Joan. 1984. Women, History, and Theory: The Essays of Joan Kelly. Women in Culture and Society Series. Chicago: University of Chicago Press.

Mann, Susan. 1997. Precious Records: Women in China's Long Eighteenth Century. Stanford, Calif.: Stanford University Press.

Perri, Elizabeth J. 2008. "Reclaiming the Chinese Revolution.” Journal of Asian Studies 67(4):1147-64.

Rofel, Lisa. 1999. Other Modernities: Gendered Yearnings in China after Socialism. Berkeley, Los Angeles, and London: University of California Press.

Scott, Joan Wallach. 1986. "Gender: A Useful Category of Historical Analysis.” The American Historical Review 91(5):1053-75.

—. 2011. The Fantasy of Feminist History. Durham, N.C., and London: Duke University Press.

Shin, Yuan-Kang. 2010. "The Isomorphism of Family and State and the Integration of Church and State: On the Differences between the Confucian Political Tradition and Democratic Politics." In Culture and Social Transformations in Reform Era China, eds. Cao Tian Yu, Zhong Xueping, and Liao Kebin, 97-118. Leiden and Boston: Brill.

Stacey, Judith. 1983. Patriarchy and Socialist Revolution in China. Berkeley, Los Angeles, and London: University of California Press.

Tsing, Anna. 2012. "On Nonscalability: The Living World Is Not Amenable to Precisionnested Scales." Common Knowledge 18(3): 505-24.

Wang Hui. 2009. "Depoliticized Politics: From East to West.” The End of the Revolution: China and the Limits of Modernity, 3-18. London: Verso.

Wolf, Margery. 1985. Revolution Postponed: Women in Contemporary China. Stanford, Calif: Stanford University Press. 